\title{
A Study on Factors Associated With Spread of Covid 19 among Health Care Delivery Workers in Jabalpur District [India]
}

\author{
Neelam Anupama Toppo ${ }^{1}$, Deepali Soni ${ }^{2}$, Priyanka Dubey ${ }^{3}$, Priyank Mishra ${ }^{4}$ \\ ${ }^{1}$ Professor in Department of Community Medicine, Netaji Subhash Chandra Bose Medical College, Jabalpur, INDIA \\ ${ }^{2}$ Post Graduate Resident in Department of Community Medicine, Netaji Subhash Chandra Bose Medical College, \\ Jabalpur, INDIA \\ ${ }^{3}$ Post Graduate Resident in Department of Community Medicine, Netaji Subhash Chandra Bose Medical College, \\ Jabalpur, INDIA \\ ${ }^{4}$ CEO Zila Panchayat, Jabalpur, INDIA
}

Corresponding Author: Dt. Neelam Anupama Toppo; neelam.philips2011@gmail.com

Received: 21 October 2020;

Accepted: 28 October 2020;

Published: 01 November 2020

\begin{abstract}
Introduction: COVID-19 is an infectious disease caused by the most recently discovered coronavirus. This new virus and disease were unknown before the outbreak began in Wuhan, China, in December 2019. One target during this pandemic is to control infection by promoting the use of Masks, hand sanitizations and maintaining the social distance. And the key spreaders as well most vulnerable for Covid-19 are Medical care staff (Doctors, Nurses, paramedical workers, ward boy etc). Objectives: To assess what factors were responsible for spread the disease and to understand the pattern of spread of COVID-19 among these workers. Methodology: An exploratory study design conducted among the COVID19 positive Doctors, Nurses, and paramedical staff working in Govt. or private set up. Through Telephonic conversation, data was collected. Result: $75 \%$ of a positive health professional was from NSCB medical college which has been designated as COVID Health Centre. The staffs are providing Critical care to Covid patients, Anaesthetics, Surgeons, Nurses, ward boys are at high risk for acquiring the disease. Out of 40 positive cases, only two had history of travel. Even people who wore PPE were also got infected. Maximum $38 \%$ were those who were wearing a mask but not all the time gloves. $20 \%$ were those who neither wearing masks nor gloves during exposure with contacts. Among those who were symptomatic most of them had fever followed by Fever with cough and cold, Fever with weaknesses and coughing, sore throat, body ache, etc. Conclusion: efforts are needed to reduce lapses in compliance with masking, use of gloves or the practice of hand hygiene and maintaining the social distancing in non-patient care areas, wards and OPDs.
\end{abstract}

Keywords: Health care workers, associated risk factors responsible for the spread of Covid-19, pattern of spread, Key spreaders

\section{Introduction}

COVID-19 is the infectious disease caused by the most recently discovered coronavirus. This new virus and disease were unknown before the outbreak began in Wuhan, China, in December 2019. COVID-19 is now a pandemic affecting many countries globally ${ }^{[1]}$.

The first case was reported in Jabalpur on 20th March 2020 with the history of International travel. Through this contact, six people got infected. The second index case also had a history of international travel but he was isolated timely and didn't spread the disease. Third index case had a travel history of other states and he quarantined himself and no one got the disease from him. Further two cases had common history of visits at a nursing home in the same period indicated that they might acquire the infection from that hospital as many patients came during that particular period from various neighboring districts. Two more cases who visited that hospital were also found to be positive for COVID 19. This group spread the disease to 24 people of that same locality. Then one prisoner was brought from Indore to Jabalpur and he found positive and Disease spread to police personnel that was 7 in number. Then another personnel of Nagarnigam who got an infection had a history to attend a meeting of an earlier positive person. And from here disease started spreading among many safaikaramchari and their contacts.

Another major rise of cases started with one broad dead case which was later found COVID positive. The 42 contacts of this dead lady got infected with covid 19. But the picture was not clear from where she got the disease.

Now we have 2359 positive cases as of $14^{\text {th }}$ August 2020 with 809 active cases and 47 deaths. The highest numbers were 
reported in the last 15 days with a maximum in a day was 143 . One target during this pandemic is to control infection (transmission of disease by breaking the chain) by promoting the use of Masks, hand sanitizations and maintaining the social distance. But from the last week of July Covid 19 enters among Medical care staff (Doctors, Nurses, paramedical workers, ward boy etc). As these groups are considered as front line workers and Key spreaders too, this study was planned to assess what factors were responsible for spread the disease among these workers and to understand the pattern of spread of COVID -19 with the expectation that it will provide a hypothetical or theoretical idea of the research problem.

\section{Methodology}

The type of this study is an exploratory study design conducted among the COVID 19 positive Doctors, Nurses, paramedical staffs working in Govt. or private set up. The first COVID-19 positive doctor was identified in Jabalpur District on July 15, 2020, then it continued till date. So far total Doctors, Nurses and paramedics affected are more than 40 in number but I did a telephonic interview with all of them after explaining the purpose of the study and taking their verbal consent with variables like a history of contact with COVID positive cases, frequency of exposure, duration of exposure, use of personnel protective measures like masks, gloves, PPE kit etc, and spread of disease to other persons.
Data were entered in an excel sheet and frequency table and graphs were generated and chi-square was applied to see the association with two variables.

\section{Results}

We interviewed 27 Doctors, 10 Nurses, one counselor, one supervisor of ward boys and one ward boy who came positive over one month in Jabalpur District. Among these, both males and females got affected equally i.e. 50\% were male and 50\% were female. According to Nguyen LH, Graham MS et all they found that in comparison with the general community, front-line healthcare workers were more frequently female, due to slightly higher prevalence of body-mass index which they found was $30 \bullet 0 \mathrm{~kg} / \mathrm{m}^{2}$ or higher and also smoking and non-steroidal anti-inflammatory drugs use was higher among them ${ }^{[2]}$.

Most of the Medical workers belonged to the Anaesthesia department (12.5\%, Gynae PGs (12.5\%) followed by Nursing college staff (10\%) and Super specialty Nurses (10\%) then Neurosurgeons $(7.5 \%)$ These are the people who are in close contact with a patient during surgery and patient care that has been provided by Nurses. There are Nurses and ward boys who were from non-patient care setup also like nursing college staff and Matron of Super Specialty Hospital. (Figure 1)

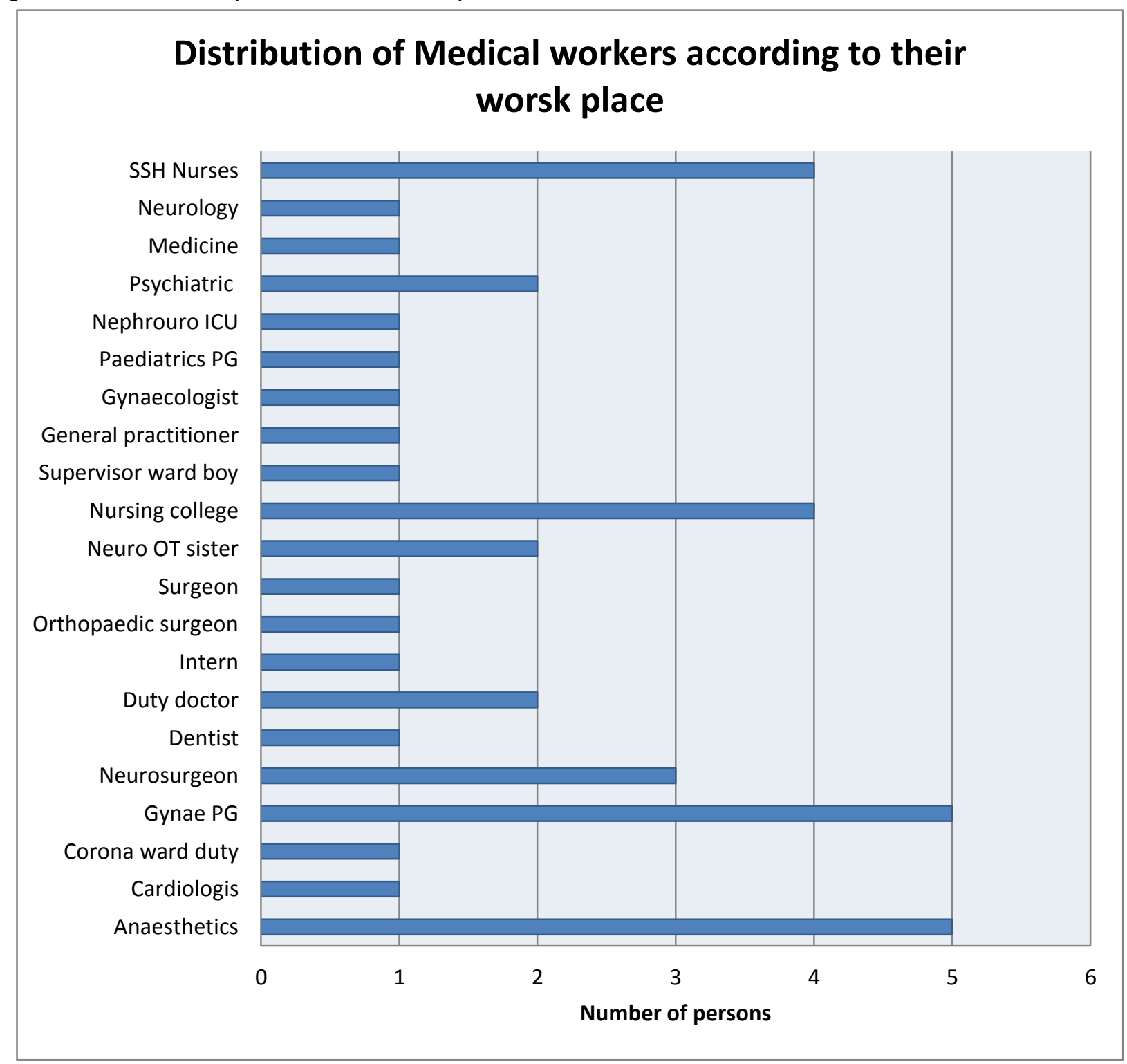

Figure 1: Distribution of medical workers according to their workplace 
Most of the Doctors, Nurses and other health workers were from NSCB Medical college which has been designated as COVID Health Centre. The staff were providing Critical care to COVID patients and were always been at high risk for acquiring the disease and its now visible in Jabalpur District that all these front line workers , Key spreaders are getting affected. (Figure 2)

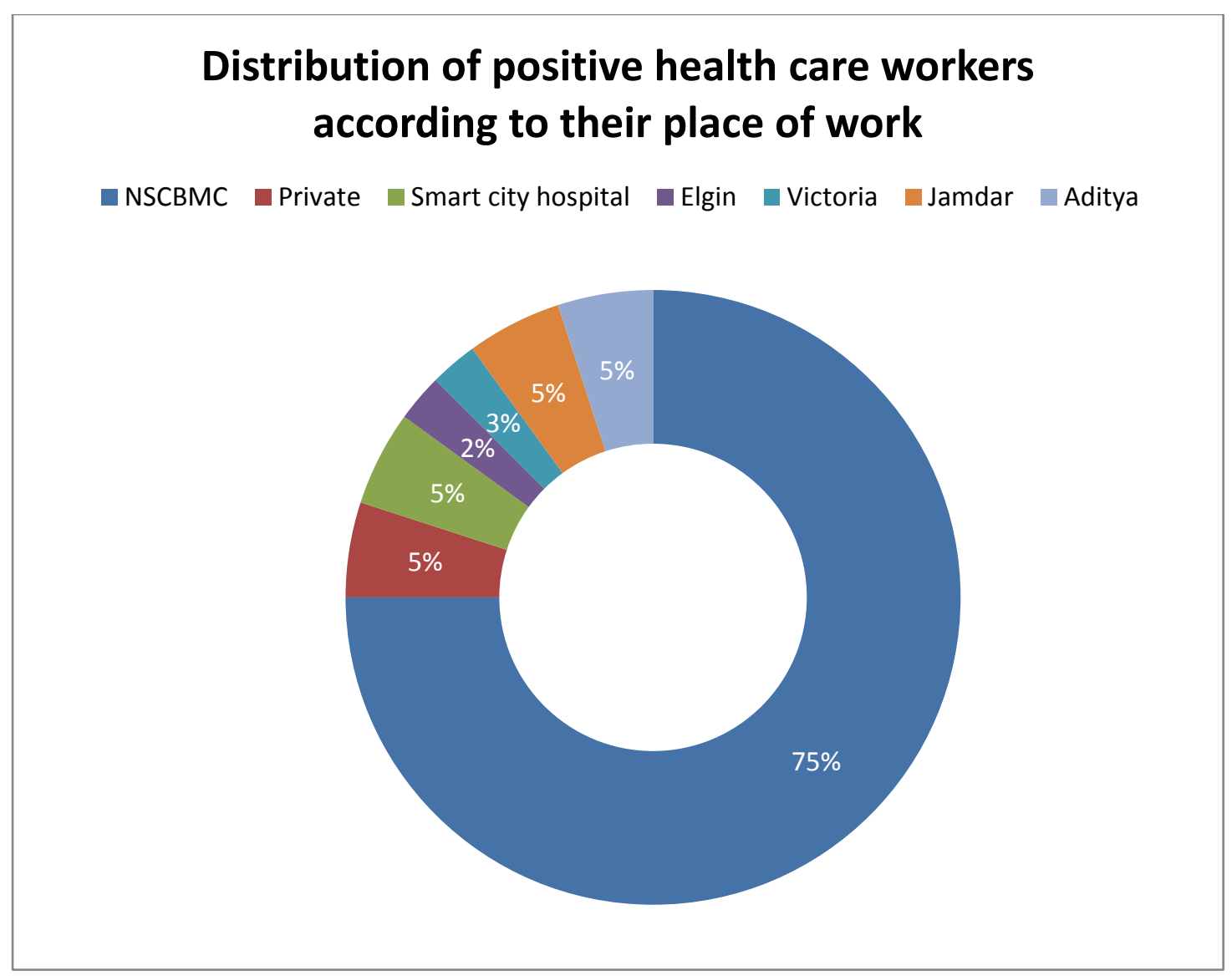

Figure 2: Distribution of positive health care workers according to their place of work

Table 1: How the chain of spread happened among medical professionals and workers in jabalpur distric?

\begin{tabular}{|c|c|c|c|c|c|}
\hline Cases & Exposure Set up & Spread to & Mode of transmission & Further spread to & Total Spread \\
\hline $\begin{array}{l}\text { Case } \\
\text { No. } 1\end{array}$ & $\begin{array}{l}\text { Wedding } \\
\text { Function }\end{array}$ & $\begin{array}{l}\text { Colleague at } \\
\text { Private } \\
\text { hospital }\end{array}$ & $\begin{array}{ll}\text { 1. } & \text { Travelled together by car to } \\
\text { neighbouring districts } \\
\text { 2. Household exposure } \\
\text { 3. } \\
\text { Breaching of use of Masks and } \\
\text { social distancing }\end{array}$ & $\begin{array}{l}\text { 1. Five family members with } \\
\text { uncle he travelled with care } \\
\text {, to aunty he went to her } \\
\text { house and put slab and } \\
\text { three cousins } \\
\text { 2. Colleague with whom they } \\
\text { sat together and had tea } \\
\text { sitting across the table }\end{array}$ & $\begin{array}{l}7 \text { over the } \\
\text { period of } \\
\text { seven days }\end{array}$ \\
\hline $\begin{array}{l}\text { Case } \\
\text { No. } 2\end{array}$ & $\begin{array}{l}\text { Hospital Setting } \\
\text { (Private Hospital }\end{array}$ & Colleagues & $\begin{array}{l}\text { 1. Sharing things with bare hands } \\
\text { 2. A surface infection like used } \\
\text { landline phone and shared scissor. }\end{array}$ & & $\begin{array}{l}3 \text { over the } \\
\text { period of } 3 \\
\text { days (August } \\
2 \text { to } 5 \text { th) }\end{array}$ \\
\hline $\begin{array}{l}\text { Case } \\
\text { No. } 3\end{array}$ & $\begin{array}{l}\text { Gynae ICU of } \\
\text { Medical College }\end{array}$ & $\begin{array}{l}\text { Colleagues } \\
\text { (PGs, SR } \\
\text { and Intern) }\end{array}$ & 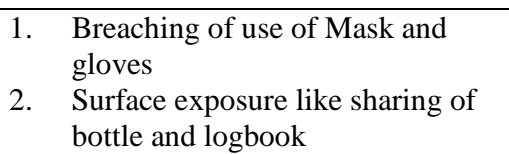 & & 5 \\
\hline $\begin{array}{l}\text { Case } \\
\text { No. } 4\end{array}$ & $\begin{array}{l}\text { Ward of Gynae } \\
\text { Department } \\
\text { (Asymptomatic } \\
\text { Patient) }\end{array}$ & PG students & $\begin{array}{l}\text { 1. Breaching of use of Masks, gloves } \\
\text { and practice of hand sanitization } \\
\text { after touching of each patients }\end{array}$ & & 3 \\
\hline $\begin{array}{l}\text { Case } \\
\text { No. } 5\end{array}$ & $\begin{array}{l}\text { Covid ward or } \\
\text { Covid duty }\end{array}$ & $\begin{array}{l}\text { Doctors, } \\
\text { Nurses, } \\
\text { ward boy }\end{array}$ & $\begin{array}{l}\text { 1. Doctor Worked for } 14 \text { days in } \\
\text { Covid ward used PPE } \\
\text { 2. Nurse worked for } 9 \text { days and one } \\
\text { N95 mask whole day used with } \\
\text { frequent changes of triple layer } \\
\text { mask } \\
\text { 3. Ward boy worked for one month } \\
\text { used PPE }\end{array}$ & & 5 \\
\hline
\end{tabular}




\begin{tabular}{|c|c|c|c|c|c|}
\hline & & & $\begin{array}{l}\text { 4. Doctor worked in field duty kept } \\
\text { used PPE in his car for two days } \\
\text { Doctor worked for } 14 \text { days in covid } \\
\text { ward and went to Bhopal in } \\
\text { Ambulace with positive patient }\end{array}$ & & \\
\hline $\begin{array}{l}\text { Case } \\
\text { No. } 6\end{array}$ & $\begin{array}{l}\text { Ward boy } \\
\text { Incharge room } \\
\text { and home }\end{array}$ & $\begin{array}{l}\text { Ward boys } \\
\text { and brother }\end{array}$ & $\begin{array}{l}\text { 1. Met with two earlier positives } \\
\text { 2. Brother came for Rakhi stayed two } \\
\text { days at home which work in Cyber } \\
\text { crime office } \\
\text { Used only cloth mask at duty and no } \\
\text { mask at home }\end{array}$ & & 2 \\
\hline $\begin{array}{l}\text { Case } \\
\text { No. } 7\end{array}$ & Hospital setting & $\begin{array}{l}\text { Doctors, } \\
\text { Nurses }\end{array}$ & $\begin{array}{l}\text { 1. Acquired from patient or ambulance } \\
\text { through which COVID and Neuro } \\
\text { patients being shifted for CTMRI } \\
\text { 2. Breaching of use of Personnel } \\
\text { protective measures } \\
\text { 3. Through Surface touch Sharing } \\
\text { Lunch } \\
\text { 4. Multiple exposure with patients and } \\
\text { colleagues at EEG room and } \\
\text { Nephro ICU }\end{array}$ & $\begin{array}{ll}\text { 1. } & \text { Sister met in ward } \\
\text { 2. } & \text { Doctor shared tiffen } \\
\text { 3. Two Sisters Met in OT } \\
\text { 4. Metron met with } 150 \text { staff } \\
\text { nurses daily at her office } \\
\text { and attended wedding treat } \\
\text { 5. One sister and doctor had } \\
\text { exposure at EEG room and } \\
\text { ICU }\end{array}$ & 7 \\
\hline $\begin{array}{l}\text { Case } \\
\text { No. } 8\end{array}$ & $\begin{array}{l}\text { OT room through } \\
\text { Patient }\end{array}$ & Anaesthetics & $\begin{array}{l}\text { Spread through Anaesthesia by putting } \\
\text { Ryles tube under GA, and done } \\
\text { intubation on patient }\end{array}$ & & 2 \\
\hline $\begin{array}{l}\text { Case } \\
\text { No. } 9\end{array}$ & $\begin{array}{l}\text { Unknown contact } \\
\text { from family/ } \\
\text { clinic }\end{array}$ & Father & $\begin{array}{l}\text { Daughter got positive then visited three } \\
\text { hospitals }\end{array}$ & & 1 \\
\hline $\begin{array}{l}\text { Case } \\
\text { No. } 10\end{array}$ & $\begin{array}{l}\text { Red zone area/ } \\
\text { hospital }\end{array}$ & Doctor & $\begin{array}{l}\text { 1. Belonged from red zone area } \\
\text { 2. Two OT technicians were positive } \\
\text { of his hospital but Used PPE }\end{array}$ & & 1 \\
\hline
\end{tabular}

Out of 40 positive cases, only two had a history of travel where one travelled from Jabalpur to Bhopal with a patient in the ambulance and another from Jabalpur to katni, sehora in AC car without mask and gloves. (Figure 3)

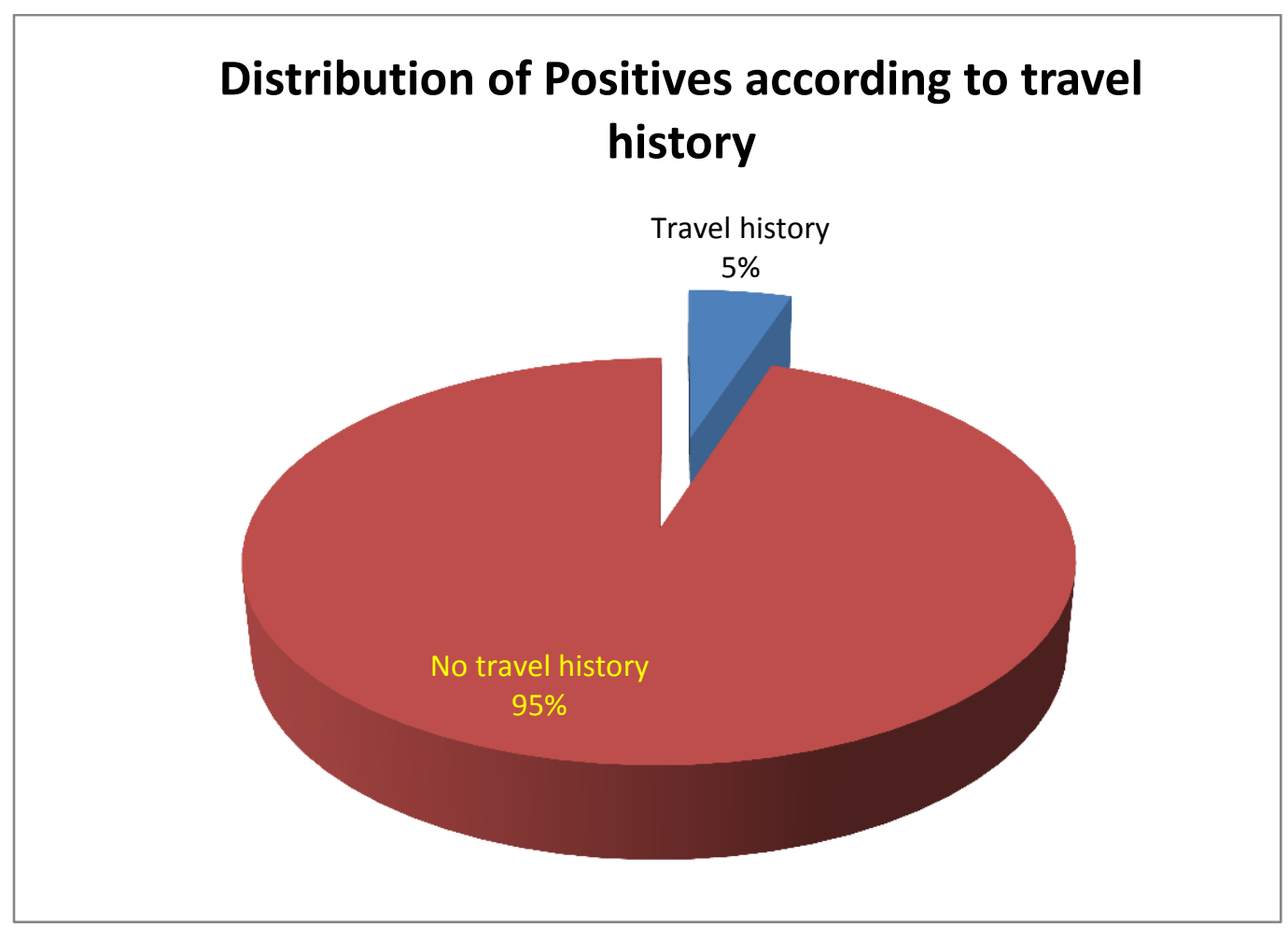

Figure 3: Distribution of positives according to travel history

The graph showing that even people who wore PPE were also got infected. Maximum 38\% were those who were wearing mask but not all the time gloves. $20 \%$ were those who neither wearing mask nor gloves during exposure with contacts. (Figure 4 and 5) 


\section{Distribution of positives according to Personal Protective Measures used}

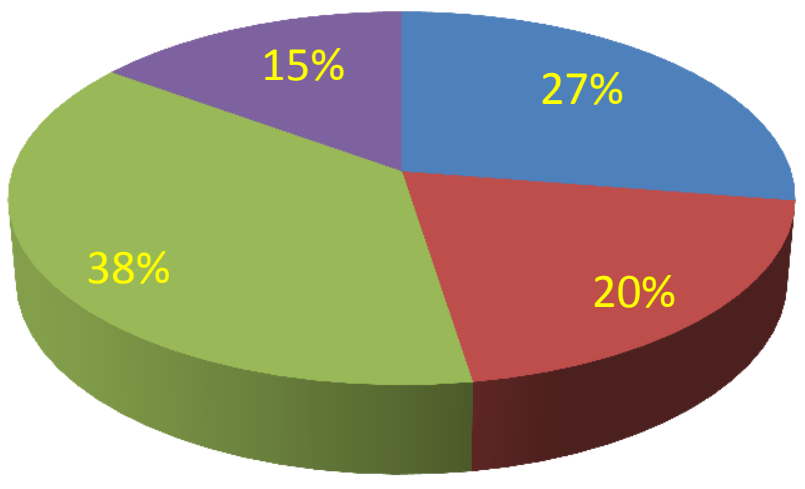

$$
\text { PPE }
$$

No mask and Gloves

Mask but not all the time gloves

mask and gloves but patient withour mask

Figure 4: Distribution of positives according to personal protective measures used

\section{Distribution of Positives according to}

\section{exposurres}

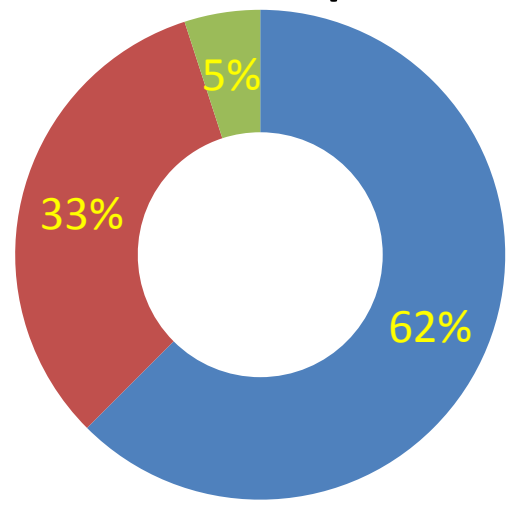

Multiple exposure

- Single exposure 13

No idea

Figure 5: Distribution of positives according to exposures

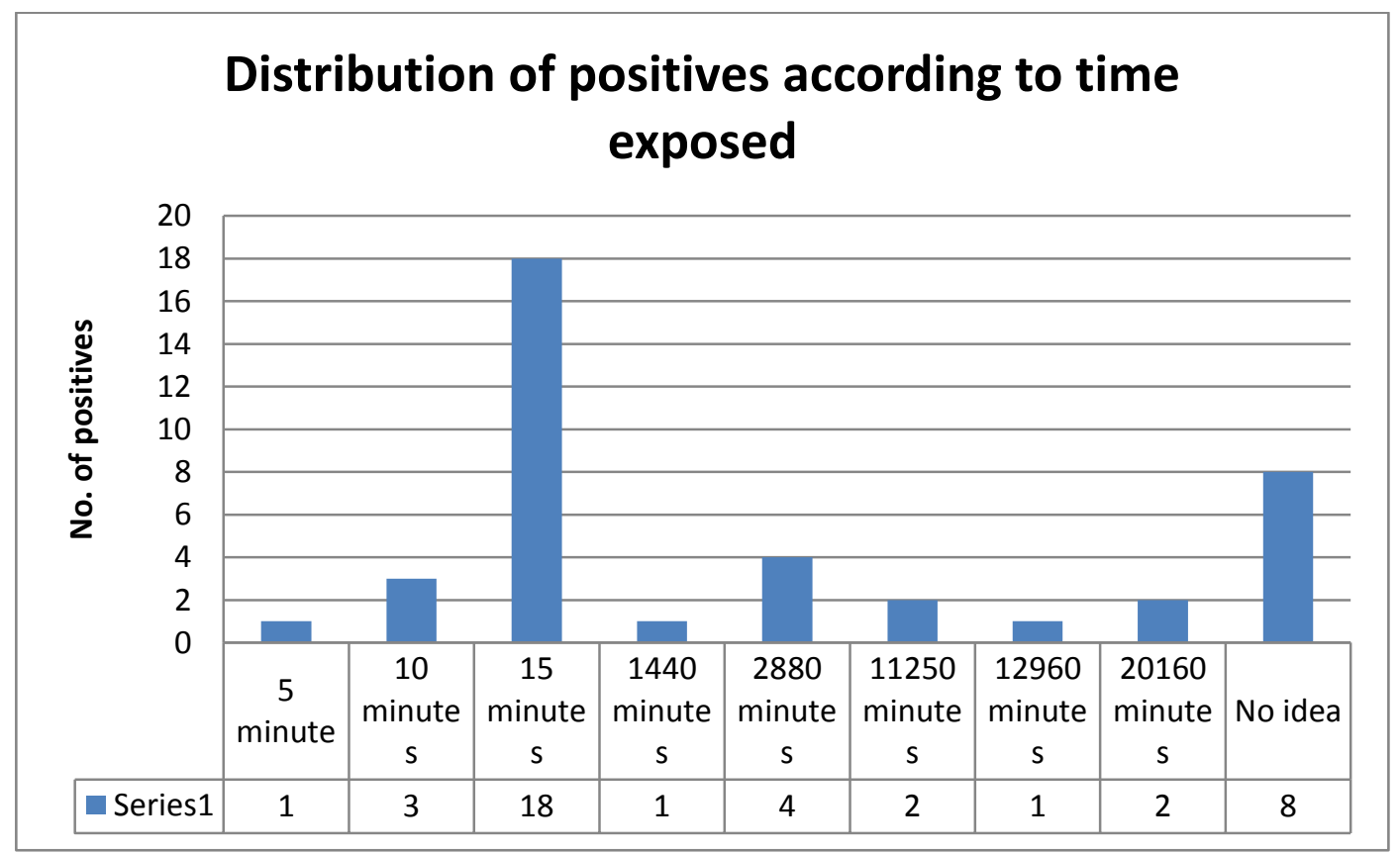

Figure 6: Distribution of positives according to time exposed 


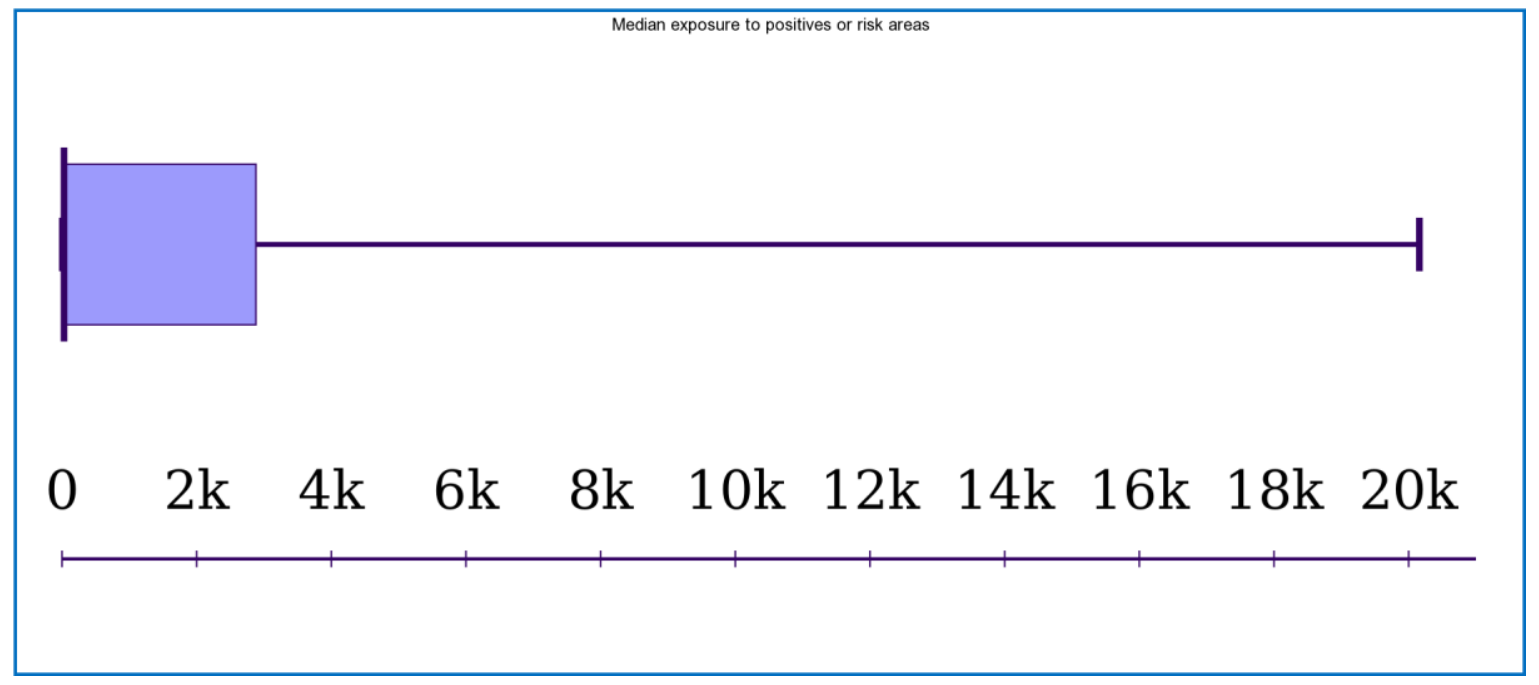

Figure 7: Median exposure times with positive cases

[Median: 30, Minimum: 5, Maximum: 20160, First quartile: 15, Third quartile: 288, Interquartile Range: 2865, Outliers: 20160 20160129601152011520 ]

Based on above data we can conclude that maximum people were those who exposed for atleast 30 minutes and people with exposed for 5 to 10 minutes were also acquired disease.

Table No. 2: Association of Symptoms and Spread of Disease

\begin{tabular}{|l|l|l|l|}
\hline Symptoms & $\begin{array}{l}\text { Disease } \\
\text { spread }\end{array}$ & $\begin{array}{l}\text { Disease not } \\
\text { spread }\end{array}$ & Row total \\
\hline Asymptomatics & $6(7)[0.14]$ & $8(7)[0.14]$ & 14 \\
\hline Symptomatics & $14(13)[0.08]$ & $12(13)[0.08]$ & 26 \\
\hline Column total & 20 & 20 & 40 \\
\hline
\end{tabular}

The chi-square statistic is 0.4396 . The p-value is .507335 . Not significant at $\mathrm{p}<.05$.

The chi-square statistic with Yates correction is 0.1099 . The pvalue is .740269. Not significant at $\mathrm{p}<.05$.
There was no significant difference for disease spread by asymptomatic or symptomatic. Asymptomatics were also equally responsible for the chain of disease spread.

Among those who were symptomatic most of them had fever followed by Fever with cough and cold, Fever with weaknesses and coughing, sore throat, body ache, etc. (Figure 8). A study on "Risk of COVID-19 among front-line health-care workers and the general community: a prospective cohort study" by Long $\mathrm{H}$ Nguyen, David A Drew et all found that $20 \cdot 2 \%$ of frontline healthcare workers reported at least one symptom associated with SARSCoV-2 infection compared with $14 \cdot 4 \%$ of the general population which were fatigue, loss of smell or taste, and hoarse voice ${ }^{[2]}$.

In another study by Li Ran,,aXuyu Chen et al found that Common symptoms were fever $(85.71 \%)$, cough $(60.71 \%)$, brachypnea $(7.14 \%)$, chest distress $(7.14 \%)$, headache $(7.14 \%)$, diarrhea $(7.14 \%)$, and hemoptysis (7.14\%) among Health care workers 28 who were diagnosed with COVID-19 ${ }^{[3]}$.

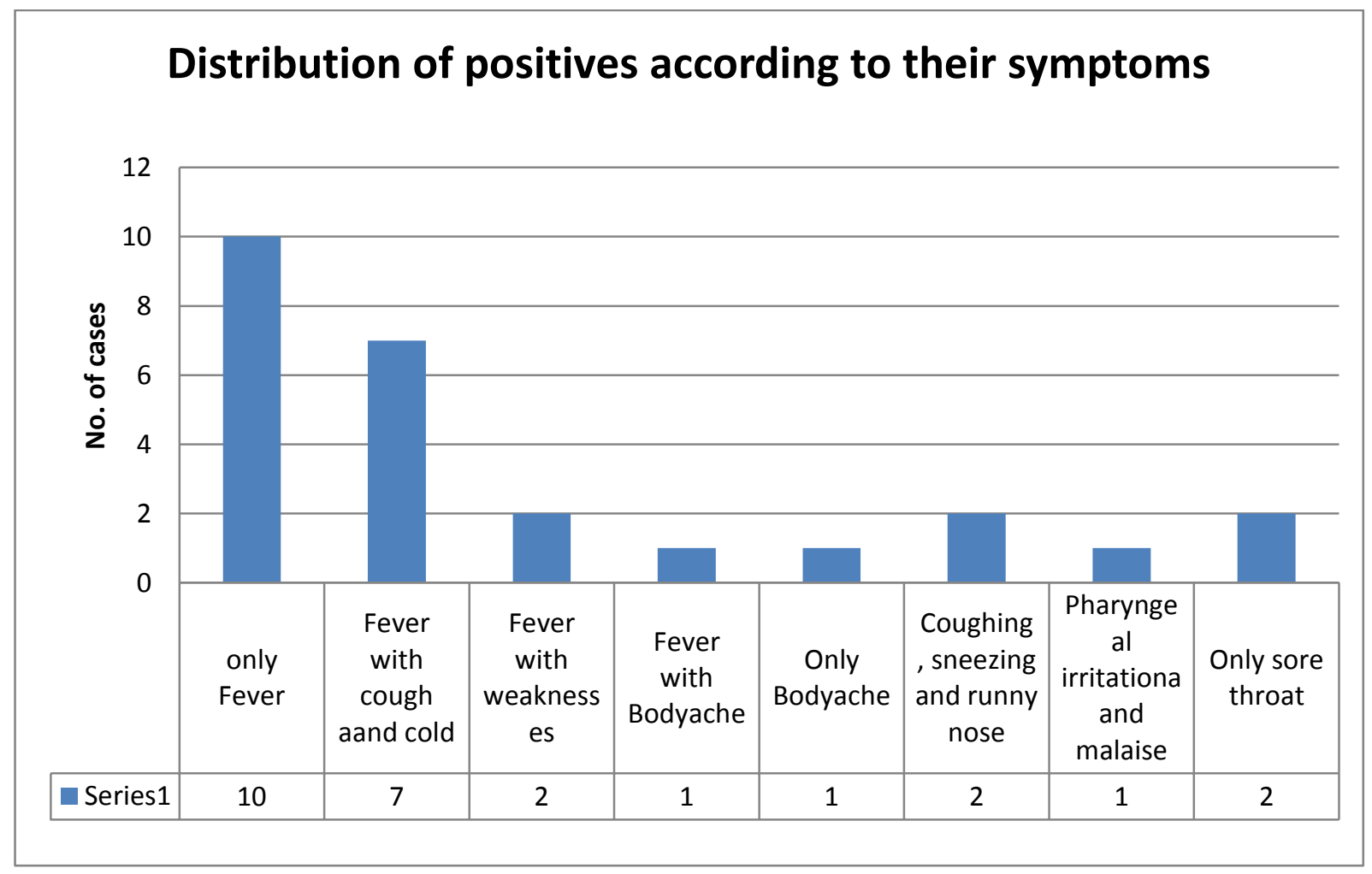

Figure 8: Distribution of positives according to their symptoms 


\section{Discussion}

We found $75 \%$ of a positive health professional was from NSCB medical college which has been designated as COVID Health Centre. The staff are providing Critical care to Covid patients, Anaesthetics, Surgeons, Nurses, ward boys are at high risk for acquiring the disease. These are the front line workers, Key spreaders are getting affected. If it will continue this will affect the Health Care delivery system of our District and this is the Tertiary care hospital for this region. Similar to our finding study by $\mathrm{Li}$ Ran, Xuyu Chen et al reported that the High-risk Department like interventional medical or surgical procedures that generate respiratory aerosols, including the respiratory department, infection department, intensive care unit (ICU), and the surgical department had 2.13 times higher risk in developing COVID-19 compared with the other general department (crude RR $=2.13$, 95\% CI: $1.45-$ $3.95, \mathrm{P}<.05)$. They also found that Contact transmission is one of the main routes of the SARS-CoV-2. Transmission from patients to Health Care workers occurred after touching either patients or fomites, whereas hand hygiene has been considered the most important preventive measure for COVID $19^{[3]}$. Our finding was also alike in their study.

As professionals acquired disease from asymptomatic patients, these findings have important implications that in such a situation a large number of hospital-acquired infections among patients, their relatives and staff will occur.

In our study, we understood that exposure to health professionals often occurred when source individuals were asymptomatic or had symptoms that were initially attributed to noninfectious conditions.

We found cases in settings like nonpatient care like nursing college and metron office where most of the staff meets regularly. The exposures were due to breaching of recommended guidelines for personnel protective measures use like masks, gloves or frequent use of sanitizers or practice of hand washings. In nursing college, one farewell party occurred where source individuals and other staff were together for a long duration. A study was done by Chatterjee $\mathrm{P}$ et all on Health Care workers and SARS Cov 2 infection in India: A case- control investigation in the time of Covid 19, reported that among the cases 57 never used PPE and 321 used PPE in all or some cases, 68 cases didn't use any mask and 310 used mask and 267 used gloves and 111did not use gloves. They concluded that appropriate use of PPE must be considered in conjunction with the risk of homeostasis operating at individual levels ${ }^{[4]}$.

There were other instances which we can consider as low risk exposures but that could potentially have resulted in transmission of disease like working in same ward, short visit in OT, EEG room, Nephro ICU as a source individual within < 1 meter distance or shared food items, water bottles that resulted as potential source of transmission.

One notable finding in our study was that 11 personnel who wore PPE also acquired infection indicates nonproper dopping and donning. Another thing was the use of N 95 mask whole day in Covid ward and triple-layer mask on $\mathrm{N} 95$ which is not the guideline was also the issue. A study done by Wang Y, Wu W et al on "Super-factors associated with transmission of occupational COVID-19 infection among healthcare staff in Wuhan, China" found a significant difference between the infected and uninfected groups, with eight factors including infection of medical staff in the same department, history of fever of medical staff in the same department, infected patients in the department, patients with fever in the department, touching the cheek, nose, and mouth during work, wearing protective medical or surgical masks correctly, selfprotection score and attending large parties or staying in crowded places for three hours or more $(\mathrm{P}<0.05)$. They concluded that not touching the cheek, nose, and mouth while working and having high self-protection scores were the two super-factors that could reduce the risk of COVID-19 infection in medical staff ${ }^{[5]}$.

But $\mathrm{Ng} \mathrm{k}$, Poon $\mathrm{BH}$ et al in their study found that $85 \%$ of health care workers were exposed during an aerosol-generating procedure while wearing a surgical mask, and the remainders were wearing N95 masks and none of the health care workers in this situation acquired infection suggested that surgical masks, hand hygiene, and other standard procedures protected them from being infected ${ }^{[6]}$.

Among Anaesthetics who got infected found that they gave anaesthesia to Covid positive cases. It indicated that this was a specific circumstance and setting where procedures like endotracheal intubation, manual ventilation before intubation, and putting a Ryles tube on patients could be the cause of the spread of disease. Chatterjee P et al also reported that Health Care Workers performed endotracheal intubation had higher odds of being SARSCoV-2 infected with [adjusted odds ratio (AOR): 4.33, 95\% confidence interval (CI): 1.16-16.07] ${ }^{[4]}$.

We also found comparatively fewer health professionals infected who were working on the COVID-19 wards or intensive care unit developed for COVID-19 patients. This could be due to known fact that all are suspected or COVID positive, minimized the risk of unprotected exposure to a patient with an unsuspected infection. Therefore we can say that compliance with universal masking was good on these wards. We can also say about the Protocols were also in place to ensure frequent cleaning and disinfection, including the nursing stations and staff work or break rooms. Ran L, Chen X et al concluded in their study that Health Care Workers who worked in HRD (High-Risk Department) and with suboptimal hand hygiene after exposure to patients were at higher risk of COVID-19. Not only that they also concluded that higher was the risk with longer duty hours ${ }^{[3]}$. Mhango M, Dzobo $M$ et al also concluded in their study that lack of and/or inadequate PPE, exposure to infected patients, work overload, poor infection control, and preexisting medical conditions put Health Care Workers at risk for nosocomial Covid-19 infection ${ }^{[7]}$.

In our study, no significant difference was found for disease spread by asymptomatic or symptomatic. Asymptomatics were also equally responsible for the chain of disease spread and we also found that maximum people were those who exposed for at least 30 minutes and people with exposed for 5 to 10 minutes were also acquired disease. While A study on infectivity of asymptomatic SARS-CoV-2 carriers by Ming Gao et al reported median contact time for patients was four days and that for family members was five days ${ }^{[8]}$. Jha S, Soni A et al reported that Health Care Workers posted in the high-risk zones had more symptoms than those working in low-risk zones $(169 / 539,31.4 \%$ vs $679 / 3128,21.7 \%), p<0.001$; but no difference they found in COVID-19 positivity rates $(\mathrm{p}=0.849)$. Symptomatic Health Care Workers had higher positivity $(10 / 193,5.2 \%)$ than the asymptomatic ones $(10 / 920,1.1 \%), \mathrm{p}=0.001^{[9]}$.

\section{Conclusion}

In our district, most of health personnel with COVID-19 had a higher-risk exposure to an infected patient or co-worker at work and general community. Improved detection of patients with atypical presentations or asymptomatics and efforts to reduce highrisk contacts among personnel may reduce the risk for acquisition 
of Covid 19. For personnel, efforts are needed to reduce lapses in compliance with masking, use of gloves of practice of hand hygiene and maintaining the social distancing in non-patient care areas, wards and OPDs.

\section{Key Lessons}

1. Whenever we let our guard down, we are at risk. In other words, even though we think we are taking precautions, there are everyday situations where we become careless.

2. Not only patients, but also colleagues must be considered a virus carrier.

3. Pre-symptomatic and asymptomatic colleagues spread infection.

4. Interacting with colleagues with mask down can be potentially dangerous.

5. Spread also happens in non-patient care areas like Nursing school, Metron office, Doctors room

6. Having lunch together, sharing water bottles involves not only lowering of mask, but also conversation (generates aerosols) and prolonged exposure time (sitting together at a table).

7. Infections occurred more in non-COVID wards - where people were less alert.

8. Patients with atypical symptoms or no symptoms at all contributed to $\mathrm{HCW}$ infections.

9. HCW can get infected outside the work place.

10. In some cases, no source was identified.

\section{Ethics approval and consent to participate}

The study was approved by the Institutional Ethical Committee and verbal consent was taken by all the participants of the study.

\section{Data Availability}

None

\section{Conflicts of Interest}

None

\section{Funding Statement}

No

\section{Authors' contributions}

NAT and PM conceptualized the whole study. NAT collected the data from study participants and analysed \& interpreted the data. NAT, DS and PD contributed in writing the manuscript. All authors read and approved the final manuscript.

\section{Acknowledgments}

We are thankful to all the participants for the co-operation and information they provided for the research.

\section{References}

[1] World Health Organization. Q\&A on coronaviruses (COVID-19) [Internet]. 2020 [Cited 23 September 2020].
Available

https://www.who.int/emergencies/diseases/novel-

coronavirus-2019/question-and-answers-hub/q-a-detail/qa-coronaviruses.

[2] Nguyen LH, Graham MS, Guo CG, Drew DA, Joshi AD, $\mathrm{Ma} \mathrm{W}$ et al. Risk of COVID-19 among front-line healthcare workers and the general community: a prospective cohort study. THE LANCET Public Health [Internet]. 2020 [Cited 21 September 2020];5(9):475-483. Available from:

https://www.thelancet.com/journals/lanpub/article/PIIS2 468-2667(20)30164-X/fulltext.

[3] Ran L, Chen X, Wang Y, Wu W, Zhang L, Tan X. Risk Factors of Healthcare Workers With Coronavirus Disease 2019: A Retrospective Cohort Study in a Designated Hospital of Wuhan in China. Clinical Infectious Diseases [Internet]. 2020 [Cited 23 September 2020]. Available from: https://academic.oup.com/cid/advancearticle/doi/10.1093/cid/ciaa287/5808788.

[4] Chatterjee P, Anand T, Singh KJ, Rasaily R, Singh R, Das $\mathrm{S}$ et al. Healthcare workers and SARS-CoV-2 infection in India: A case control investigation in the time of COVID-19. Indian Journal of Medical Research [Internet]. 2020 [Cited 23 September 2020];151(5):459467. Available from: http://www.ijmr.org.in/article.asp?issn=09715916; year=2 $020 ;$ volume $=151 ;$ issue $=5 ;$ spage $=459 ;$ epage $=467 ;$ aulast $=\mathrm{c}$ hatterjee.

[5] Wang Y, Wu W, Cheng Z, Tan X, Yang Z, Zeng X et al. Super-factors associated with transmission of occupational COVID-19 infection among healthcare staff in Wuhan, China. Journal of Hospital Infection [Internet]. 2020 [Cited 21 September 2020];106(1):25-34. Available from:

https://www.journalofhospitalinfection.com/articleS0195 -6701(20)30308-X/fulltext.

[6] Ng k, Poon BH, Puar THK, Quah JLS, Loh WJ, Wong YJ et al. COVID-19 and Risk to Health Care Workers: A case Report. Annals of Internal Medicine [Internet]. 2020 [Cited 22 September 2020]; 172(11):766-767. Available from: https://www.acpjournals.org/doi/10.7326/L200175 .

[7] Mhango M, Dzobo M, Chitungo I, Dzinamarira T. COVID-19 Risk Factors among Health Workers: A Rapid Review. Safety and Health at Work [Internet]. 2020 [Cited 22 September 2020];11(3):262-265. Available from: https://www.sciencedirect.com/science/article/pii/S20937 91120302961.

[8] Ming Gao , Lihui Yang, Xuefu Chen , Yiyu Deng , Shifang Yang, Hanyi Xu, Zixing Chen, Xinglin Gao . A study on infectivity of asymptomatic SARS-CoV-2 carriers. Respir Med. 2020 Aug; 169:106026. doi: 10.1016/j.rmed.2020.106026. Epub 2020 May 13.

[9] Jha S, Soni A, Siddiqui S, Batra N, Goel N, Dey S et al. Prevalence of Flu-like Symptoms and COVID-19 in Healthcare Workers from India. Journal of the Association of Physicians of India [Internet]. 2020 [Cited 22 September2020]; 68. Available from: https://www.japi.org/w2f4d444/prevalence-of-flu-likesymptoms-and-covid-19-in-healthcare-workers-fromindia. 